\title{
DIE PREDIKER AS PREEK BASISTEORETIESE PERSPEKTIEWE UIT HANDELINGE
}

\author{
C.J.H. Venter ${ }^{1}$ en H.K. Kim ${ }^{2}$
}

ABSTRACT

\section{THE PREACHER AS SERMON}

This article explores the topic from a pneumatological perspective, and pays attention to the preacher's calling, appointment and being filled with the Holy Spirit. The key question is that of congruence between what a preacher preaches and how he lives his life (i.e. as a sermon). The following issues from the book of Acts are dealt with: the passion of the preacher for congruence between preacher and sermon; the integrity to proclaim God's total plan of salvation; humility, the courage and boldness in preaching the Word of God; the will to suffer hardship in absolute obedience to God, and the holy indignation when God is not honoured. Issues relating to attitude in prayer and in Scripture reading, meditation and application of the Word are investigated as these contribute to the congruence between preacher and sermon.

\section{OPSOMMING}

\section{DIE PREDIKER AS PREEK}

Vanuit 'n pneumatologiese vertrekpunt, waarin die roeping, vervulling en aanstelling deur die Heilige Gees in fokus gebring word, word hierdie onderwerp nader bestudeer. Die kernvraag handel oor die kongruensie tussen wat die bedienaar preek en hoe hy lewe. Die volgende inhoudelike aspekte uit die boek Handelinge word ontgin: passie van die prediker om as preek te lewe, innerlike getrouheid en integriteit om God se heilsplan te verkondig, nederigheid, moed en vrymoedigheid om te dien, bereidheid om lyding vir die evangelie te verdra en te vervul, absolute gehoorsaamheid aan God en heilige verontwaardiging waar sy eer nie gehandhaaf word nie. Nederigheid in sy gebedslewe en toewyding in en oopstelling van sy eie gemoed in sy bestudering van die Woord, bevorder kongruensie tussen prediker en preek.

1 Prof. C.J.H. Venter, Departement Praktiese Teologie, Skool vir Kerkwetenskappe, Universiteit van die Noordweste, Potchefstroom-kampus, Privaatsak X6001, Potchefstroom 2520. E-pos: kwscjhv@puknet.puk.ac.za

2 Dr. H.K. Kim, Vakgroep Praktiese Teologie, Skool vir Kerkwetenskappe, Universiteit van die Noordweste, Potchefstroom-kampus, Privaatsak X6001, Potchefstroom 2520 . 


\section{ORIËNTERING}

Dit is 'n wêreldwye verskynsel dat lidmaatgetalle, veral van hoofstroomkerke, 'n dalende tendens vertoon. Hierdie tendens is opmerklik in die Verenigde State, Kanada en ook in Europa (Kim 1999:3; Green 1996:9). Sedert 1981 is ook 'n dalende tendens waarneembaar in lidmaatgetalle in Suid-Afrika (Hendriks 1995:40-41). In hierdie verband word die sogenaamde "fossileringverskynsel" meermale aangedui as die oorsaak vir getallevermindering (Kim 1993:77). Fossilering dui op gebrek aan vitaliteit, leë kerke, formalisme in die geloofslewe, verlies aan passie vir evangelisering, oppervlakkige aanbidding en eredienste en skeptisisme by jonger mense oor die kerk as instelling.

Uiteraard word meer oorsake aangevoer vir hierdie toestand. Die dalende geboortesyfer mag ' $\mathrm{n}$ rede wees vir die vermindering in lidmaatgetalle (Mulder 1991:205). Demografiese verskuiwings kan 'n verdere moontlike oorsaak wees vir dié verskynsel. Kerke in die middestad kwyn in getalle, terwyl kerke in voorstede soms sterk groei. 'n Volgende oorsaak kan moontlik gesoek word in burokratiese leierskap (Lutzer 1998:11, 13).

'n Kardinale element in die beoordeling van dalende lidmaatgetalle mag ook geleë wees in die prediking, want "with its preaching Christianity stands or falls" (Kim 1999:4). 'n Verval of verskraling in die prediking kan onder andere aan drie faktore toegeskryf word: sekularisasie, die invloed van postmodernisme waarin die Woord van God nie meer as absolute waarheid aanvaar word nie en die kubernetiese omwenteling wat die eenrigtingverkeer-kommunikasie in die preek bevraagteken (Vorster 1996:71-72).

Dit gaan egter nie net om die prediking nie, maar ook om die prediker, "the problem is usually preachers themselves who may have lost power and love toward God and man" (Kim 1999:4-5; vgl. Runia 1983:15; Mawhinney 1997:25-33).

In navorsing op die vlak van die Homiletiek word vir baie jare al gefokus op preke en die samestelling van preke. Hierin is gedeë navorsing gedoen. Dit is egter in die afgelope aantal jare dat navorsing sterker gerig word op die prediker self (vgl. Lutzer 1998:59-65). Die navorsing oor die prediker self beweeg tans na "... a search for congruence by interpreters between the words said and the life lived" 
(Keller 2002:4). Waar' 'n gemeentelid 'n inkongruensie opmerk tussen wat die prediker sê en hoe hy in werklikheid sy lewe leef, verskaf dit aan die gemeentelid "a reason not to feel accountable to apply what they heard" (Keller 2002:4). Navorsing toon aan dat predikers wat van hart tot hart in hulle preke met vandag se gemeentes wil kommunikeer, eers van hulle persoonlike toewyding aan God 'n prioriteit moet maak. Welsprekendheid in 'n preek is belangrik, maar nie voldoende nie. 'n Preek vloei tog voort uit die diepste innerlike self van die prediker (vgl. Robinson 1999:20).

Bogenoemde navorsing oor die prediker, sy lewe en gesindheid, is ook gestimuleer vanuit ' $\mathrm{n}$ wyer agtergrond. Craddock het naamlik 'n nuwe wending ingelei in homiletiese navorsing, nie net met sy induktiewe metode van preek nie, maar ook deur sy aksent op die hoorders van die preek. Nie net die teks nie, maar ook die hoorders moet geïnterpreteer word. In hierdie interpretasieproses moet beide die prediker en die gemeente die teks as't ware van vooraf ervaar (Craddock 1985:226). Hierdie ervaring moet spruit uit die "inner depths of the preacher" (Mitchell 1993:227). Die inkorporering van die interpretasie van die gemeente stel bepaalde geloofs- en gesindheidsvereistes aan die prediker, byvoorbeeld vereistes ten opsigte van gesag in die bediening van die Woord, pastorale ingesteldheid en empatie. Craddock se beklemtoning van die plek van die hoorder word voortgesit in die homiletiese werk van Buttrick (1994:112-113).

Wat die Europese navorsingstoneel betref, is dit veral Dingemans wat in 1991 'n omvattende homiletiese werk die lig laat sien. Hierin skenk hy aandag aan 'n hermeneutiese homiletiek. Hy stel onder andere dat preke van 'n prediker wat in eie gesag vanuit 'n verhewe posisie wil preek en koerse aandui, nie lewensvatbaar is nie. Gesag word nie aan die persoon van 'n prediker verbind nie, maar aan die (suiwer) Woord wat gebring word (vgl. Dingemans 1991:21 e.v.)

Wat die Suid-Afrikaanse navorsingstoneel betref, het Vos (1995) en Pieterse (2001) waardevolle bydraes gelewer oor aspekte wat in hierdie artikel nader ontgin gaan word. Die aandag word egter veral gevestig op die werk van Malan Nel waarin hy op indringende wyse aandag skenk aan aspekte wat die preek (lewe) van die bedienaar raak, asook aan die uitwerking daarvan op die pastorale- en preekwerk op 
die kansel. Hy behandel sake soos die persoon, persoonlikheidsontwikkeling en persoonlikheidstipe van 'n prediker. Hy kom tot die slotsom dat persoonlikheid kommunikeer (Nel 2001:13-39). Hierby besin Nel (2001:45-65) verder oor sake soos egtheid, opregtheid en die manifestering van gesag in die optrede van die prediker. Hy bepleit ' $n$ lewe van selfstandige geestelike funksionering, van onderskeidingsvermoë en van kreatiwiteit (Nel 2001:84-97).

Aspekte wat hierbo uitgelig is in veral resente homiletiese teorievorming, kan herlei word tot een begrip, naamlik kongruensie in die lewe van 'n prediker tussen wat gepreek word en gedoen word. Hierdie kongruensie tussen wat 'n prediker preek en wat hy doen, word gevoed deur, en vind sy oorsprong in kongruensie tussen prediker en God. Outeurs noem hierdie kongruensie ook identifikasie tussen prediker en God,

... unless the preacher spends time with God, allowing His essence to flow through and change from within, he may be a good performer, (but) the prophetic impact of the message is inhibited the incarnation is the essential act of identification (Keller 2002:4).

Wat hierbo beredeneer is, verklaar die titel van hierdie artikel nader. Die prediker (soos hy Sondae vir die gemeente preek) as preek (soos sy lewe, optrede, voorbeeld en toewyding na die gemeente en buitestaanders deurkom) - dit is die tema wat nader verken gaan word, juis ook met die oog op 'n nadere fundering van aspekte wat verband hou met die lewe van 'n prediker. Die metode wat gevolg word, is die van analise, interpretasie en sintese van materiaal uit toepaslike bronne.

Voorts word die aandag daarop gevestig dat vir die ontginning van basisteoretiese materiaal besonderlik gefokus word op die boek Handelinge. Die motivering hiervoor is dat die boek Handelinge homileties nog onvoldoende verken is in prakties-teologiese navorsing en dit terwyl die boek Handelinge te doen het met prediking in die vestiging en uitbreiding van die kerk ná die uitstorting van die Heilige Gees. Preke en toesprake beslaan ongeveer die helfte van die boek Handelinge (Kistemaker 1995:8; vgl. Johnson 1997:11). Hierin staan drie preke van Paulus besonderlik op die voorgrond. Dit is die preek aan die Jode in Antiochië (Handelinge 13), die in Athene aan ongelowiges (Handelinge 17) en die preek in Miletus aan die ouderlinge van Efese (Handelinge 20). 
Die navorsingshipoteses is dat ' $\mathrm{n}$ verkenning van basisteoretiese gegewens uit Paulus se preke in Handelinge 13, 17 en 20 nadere riglyne kan bied vir die kernnavorsingsvraag: "Hoe moet die preek (die lewe) van die prediker wees om in kongruensie met mekaar te wees en te bly?"

\section{DIE PREDIKER AS PREEK}

\subsection{Pneumatologiese vertrekpunte}

Dit is belangrik dat 'n pneumatologiese vertrekpunt vir bestudering van die lewe van die prediker geneem word; juis om te bevestig dat die preek (lewe) van die prediker nie primêr bepaal word deur psigologiese samestelling, persoonlikheidstruktuur of eie hantering van stres nie, ook nie primêr deur kommunikasievaardighede of skerp insig in tendense van ons tyd nie. Primêr is dit die Heilige Gees se werk om prediker en preek in kongruensie te bring en te hou.

Op meer plekke in die Nuwe Testament word die lewe en optrede van die prediker verbind aan die werking van die Heilige Gees. In Efesiërs 1:13 word byvoorbeeld gestel: "In Christus het die Heilige Gees ... julle (= die kerk) beseël as eiendom van God". "Beseël" het die nuanse van "veilig bewaar (verpak) om die eindbestemming te bereik". Dieselfde gedagte van beseël word weer in Efesiërs 4:30 gebruik en direk verbind met "En moenie die Heilige Gees van God bedroef nie..."

Die voorskrifte uit Efesiërs 5:6-20 hoe om te lewe as mense van die lig, loop as't ware in vers 18 uit op: "Laat die Gees julle vervul ..." Uiteraard geld wat hierbo beredeneer is, vir elke gelowige en dus ook vir die prediker.

In 2 Timoteus 1:7 word die werk van die Heilige Gees direk verbind met die gesindheid waarin 'n prediker sy werk moet verrig en sy lewe moet lei. "Die Gees wat God ons gegee het, maak ons immer nie lafhartig nie, maar vul ons met krag, liefde en selfbeheersing". Liefde en selfbeheersing word in Galasiërs 5:22 direk verbind met die vrug van die Heilige Gees.

Die vraag hier is nou of in die genoemde preke in Handelinge aanduidings is van die werk van die Heilige Gees in die prediker as preek. Vier gedeeltes word hiervoor verken. Eerstens, Handelinge 13:2: 
Toe hulle op 'n keer bymekaar was om die Here te dien en om te vas, het die Heilige Gees gesê: Sonder Barnabas en Paulus vir My af om die werk te doen waarvoor Ek hulle geroep het.

Hier word eksplisiet gestel dat die Heilige Gees twee dinge doen: Die Gees beveel: "Sonder af" en "Ek het hulle geroep". "Afsonder" het in Grieks die nuanse van afsonder van die res, van 'n bepaalde beroep vir ' $n$ ander buitengewone saak. Die uitdrukking het hier 'n dringendheid wat weergegee kan word met "Sonder nou (dadelik) af" (vgl. Kim 1999:128).

Die dringendheid van die opdrag word nog verder beklemtoon deurdat die Heilige Gees self hier aan die woord is in "Ek" (die eerste persoon-terme), as mondstuk van God en Jesus self. Die erns waarmee die Heilige Gees afsonder, word bevestig deur die tweede aksie, naamlik "roep". Wat hier na vore kom is roeping vir, letterlik na, 'n baie spesifieke opdrag.

Die kardinale plek en werk van die Gees wat die prediker afsonder en roep, is hiermee blootgelê. Prediker en preek kan alleenlik dan in kongruensie met mekaar wees indien besef word dat God die Heilige Gees 'n bedienaar afsonder as prediker en roep om as afgesonderde te preek (lewe).

Tweedens, Handelinge 20:28:

Pas julleself op en die hele kudde wat die Heilige Gees onder julle sorg gestel het.

Dit is opvallend dat die werk van die Heilige Gees in hierdie vers voorafgegaan word deur die opdrag "Pas julleself op". Later gee Paulus dieselfde opdrag aan Timoteus: "Let op jouself". Hierdie bevel staan ook in direkte verband met die prediker as preek. Kongruensie tussen prediker en preek begin by selfsorg ten opsigte van gedrag, optrede en lewenswandel.

Die Heilige Gees het die kudde gestel, geplaas, onder die sorg van die ouderlinge. Die implikasie hiervan is dat die ouderlinge aangestel is omdat dit vir almal duidelik was dat hulle vervul is met die Heilige Gees en toegerus is deur dieselfde Gees om herders vir die gemeente te wees (vgl. Phillips 1991:405). Dat die Heilige Gees ouderlinge as herders aanstel hou ook in dat die Heilige Gees hulle 
toerus om herders te wees — en om so ook die gemeente weer te kan toerus.

Kongruensie tussen prediker en preek is net moontlik as die perspektief behou word dat die Gees aanstel, toerus, met herdersharte - en self ' $n$ Herder is vir die prediker om te kan preek (sy lewenswandel).

Derdens, Handelinge 13:9:

Maar Saulus, dit is Paulus, vol van die Heilige Gees, het hom skerp aangekyk en gesê ...

Hoewel die Heilige Gees elke ware gelowige vervul, is dit tog so dat die krag van die Heilige Gees ook besonderlik teenwoordig en werksaam is, soos hier waar Paulus met die Satan self te doen het in die optrede van Elimas. "Vol van die Heilige Gees" kan hier weergegee word met "die Heilige Gees het volkome van hom besit geneem", of "die Gees het hom volkome beheer" (vgl. Rienecker 1980:192), of "hom bekragtig deur sy teenwoordigheid". Juis om hierdie rede veroordeel Paulus vir Elimas met soveel vrymoedigheid, uitgesprokenheid en krag.

Uit hierdie gedeelte kom duidelik na vore dat die prediker as preek met die aanslag van die duiwel te doen sal kry en net kan oorwin en staande bly deur die vervulling van die Heilige Gees.

Vierdens, Handelinge 20:22-23:

En nou gaan ek Jerusalem toe, daartoe gedwing deur die Heilige Gees. Wat daar met my sal gebeur, weet ek nie. Ek weet dat die Heilige Gees my in elke stad verseker dat gevangenskap en vervolging op my wag.

Twee aksies word hier aan die Heilige Gees toegeskryf. Die eerste is dat die Gees Paulus "dwing". Letterlik staan hier dat Paulus deur die Heilige Gees gebind is, as't ware geboei is. (Die uitdrukking "boeie" word juis ook in vers 23 gebruik!) Hierdie gedagte hou in dat Paulus gehoorsaam is aan die "binding" van die Heilige Gees. Hy bepaal nie self sy toekoms nie. Juis om hierdie rede is daar 'n verband tussen Paulus se gebind wees deur die Gees en sy afsondering deur die Heilige Gees en sy roeping tot hierdie bepaalde taak om na Jerusalem te gaan. 
Sy gehoorsaamheid veronderstel 'n vermoë om met toekomstige onsekerheid saam te leef (vgl. Kistemaker 1995:729).

Die uiteensetting hierbo dui ook op 'n kardinale vereiste aan die prediker as preek. Gebind deur die Gees vorm die brug tussen 'n toegewyde prediker en 'n preek (lewe) vanuit totale toewyding en oorgawe aan die Heilige Gees.

\title{
2.2 Die prediker as preek — inhoudelike aspekte
}

\subsubsection{Preek (lewe) as passie vir die evangelie}

Handelinge 20:24 word ook hier as toepaslik beskou:

\begin{abstract}
Maar al is my lewe vir my kosbaar, reken ek dit van geen belang nie as ek maar net my lewenstaak kan voltooi en die dienswerk wat ek van die Here Jesus gekry het, kan klaarmaak: dit is om die evangelie van God se genade te verkondig.
\end{abstract}

Paulus is deur die Heilige Gees gedwing om na Jerusalem te gaan. Tog, aan die ander kant het die Heilige Gees hom ook gewaarsku oor swaarkry en selfs gevangenskap en vervolging wat op hom wag. Alhoewel Paulus reeds baie lyding verduur het (2 Korintiërs 11:23-29), weet hy dat hy in Jerusalem en elders die lyde van gevangenskap sal moet verduur. Tog bly hy vasberade om te gaan (vgl. Phillips 1994: 403). Dit kan hy doen vanuit 'n diepe passie

vir die verkondiging van die evangelie: as ek maar net my lewenstaak kan voltooi ... en my dienswerk kan klaarmaak.

Kim (1999:94) meen dat ons hier 'n vermenging van twee uitdrukkings het: "I have regard for nothing" en "I do not consider my life precious". Selfs in die lig van komende gevangenskap en lyding, relativeer Paulus sy (aardse) bestaan. Hy wil dit nie ten alle koste behou nie:

He rather chooses to pursue the purpose the Lord Jesus has for him: the task of testifying to the gospel of God's grace (Marshall 1991: 332).

Preek as lewenswyse hou dus hier in om vanuit passie vir die evangelie bereid te wees om te sterf vir die evangelie. Hierdie gesindheid loop soos 'n draad ook deur van Paulus se ander briewe (2 
Korintiërs 4:7-5:10; 6:4-10; 12:9; Filippense 1:19-26; 2:17; 3:8; Kolossense 1:24). Passie is dus nie om ten alle koste te bly leef nie, maar om die taak deur God opgedra, te voltooi.

\subsubsection{Preek (lewe) as moed om te verkondig}

Hier word aandag gewy aan Handelinge 13:45-46:

Toe die Jode die groot opkoms sien, is hulle met afguns vervul en het hulle telkens Paulus se woorde teëgespreek en hom beledig. Paulus en Barnabas het reguit vir hulle gesê: "Die Woord van God moes eerste aan julle verkondig word, maar omdat julle dit verwerp en daarmee bewys dat julle die ewige lewe nie werd is nie, gaan ons nou na die mense toe wat nie Jode is nie".

Oproer ontstaan vanweë die Jode se onwilligheid om ook heidene wat kom luister, in die volk van God te aanvaar. "Instead of obeying the teaching of God's word, they began to contradict the words spoken by Paul" (Kistemaker 1995:493).

In sy reaksie hierop praat Paulus "reguit" (1983 Afrikaanse Vertaling) met hulle. Die uitdrukking wat hier gebruik word, dui sterk op vrymoedigheid, oortuiging, 'n vaste karakter, om te praat uit ervaring:

It combines the emphasis of "I know this is true because its happened to me" with a "thus saith the Lord" as emphasis (vgl. Ogilvie 1984:90).

In Hebreërs 10:19 word dieselfde uitdrukking vir vrymoedigheid gebruik, maar vertaal met "vrye toegang". Die uitdrukking "vrymoedigheid" het ook 'n konnotasie van "reg" — die reg van 'n Griekse burger om voluit sy saak te stel op 'n volksvergadering.

Dieselfde begrip ("vrymoedigheid) word in Handelinge 14:1-3 gebruik waar Paulus en Barnabas, ten spyte "van die oproer van die Jode, in die stad aangebly en in vertroue op die Here onbevrees gepreek het". Onbevrees (met vrymoedigheid) preek, impliseer hier om te preek en niks terug te hou nie - al is daar rede vir vrees (vgl. Calvyn 1966:2). Hierdie ongeïnhibeerde vrymoedigheid om te preek is nie die vrug van die apostels se eie dapperheid nie; dit is 'n geskenk van God, gewerk deur die Heilige Gees (Johnson 1997:223). 
Prediker en preek is dus 'n eenheid waar die Heilige Gees die moed as vrymoedigheid skep om te verkondig en self te leef uit die verkondiging.

2.2.3 Preek (lewe) as getroue verkondiging van die volle heilsplan van God

In Handelinge 20:27 word gestel:

... want ek het nie nagelaat om die heilsplan in sy volle omvang aan julle te verkondig nie.

Paulus is hier besig om afskeid te neem van die ouderlinge in Efese. Hy het sy deel getrou en voluit gedoen. As iemand verlore sou gaan, sou dit nie Paulus se skuld gewees het nie. Waarom nie? En dan volg vers 27 soos hierbo aangehaal.

Die uitdrukking "nie nagelaat nie" is deel van Lukas se mediese woordeskat en is gebruik vir die aksie om voedsel van pasiënte te weerhou (Phillips 1991:401). Juis dít het Paulus nooit gedoen nie. Uit die Woord het hy die gemeente van gebalanseerde voedsel voorsien. In die uitdrukking "nie nagelaat nie", is ook die volgende nuanse ingebed: "nie terugdeins om die waarhede te preek nie — selfs teen teenstand in - wat die gemeente nodig het vir hulle saligheid en vir hulle geloofslewe" (Keddie 1993:257).

Die uitdrukking "die volle raad van God", sou ook vertaal kon word met "alles wat God beplan om te doen". In hierdie uitdrukking word die idee van doel en beplanning ook saamgevat. Juis daarom verwys "raad van God" meermale na die goddelike plan van versoening deur die lyding van die beloofde Messias (Handelinge 13:46). Wat hier in kern gestel word, is die genoegsaamheid van die historiese openbaring en die oordrag daarvan deur die verkondiging van die woord (Williams \& Larkin 1995:297).

Calvyn (1966:180) bou op die gedagte van getroue verkondiging voort as hy stel dat die uitdrukking "volle raad van God" 'n kernsamevatting is hoe om korrek te preek en ook hoe bedienaars wat self uit die Woord lewe, hulleself aan hierdie taak ten volle moet toewy:

The preacher should not use his own judgement to determine what is suitable to present in public and what to omit (Calvyn 1966:80). 
Prediker as preek hou ook in 'n innerlike getrouheid en integriteit om wat ookal in die Skrif geopenbaar word, vrymoedig te preek en toe te pas in die lewe van die prediker self (in eerste instansie) maar ook in die lewe van die gemeente. Dit is waarskynlik met hierdie woorde in gedagte dat Paulus in 1 Timoteus 4:6 aan Timoteus sê:

As jy hierdie dinge aan die broers (gemeente) voorhou, sal jy 'n goeie dienaar van Christus Jesus wees wat jouself voed met die woorde van die geloof en die goeie leer waarvan jy 'n aanhanger geword het.

\subsubsection{Preek (lewe) as nederigheid}

Handelinge 20:18-19:

Toe hulle by hom kom, sê hy vir hulle: "Julle weet hoe ek die hele tyd van die eerste dag af dat ek in die provinsie Asië gekom het, onder julle geleef het; hoe ek die Here in alle nederigheid gedien het ..."

In hierdie gedeelte is twee uitdrukkings wat mekaar aanvul, naamlik "dien" en "nederigheid". Die diens wat Paulus gelewer het, word hier beskryf as slawediens. Ware nederigheid begin by die innerlike besef: "Ek is 'n slaaf van die Here". Hier word die naam Kurios gebruik as aanduiding daarvan dat hy, Paulus, as 'n slaaf van die opgestane Here, die Oorwinnaar, diens gelewer het. Hy het geen grond gehad om trots te wees nie. Sy trots lê in die feit dat hy dien as slaaf van die Kurios. 'n Slaaf het as slaaf geen gesag in homself nie. Die woord van die Kurios, wat deur die slaaf bedien word, het gesag.

By hierdie slaaf-wees van Paulus sluit die begrip "nederigheid" aan. Nederigheid hou in die erkenning van eie swakheid, maar ook die ervaring van God se krag, grootheid en heiligheid (Rienecker 1976:317).

Die kongruensie tussen prediker en preek (lewe) word gevorm deur slawediens en nederigheid.

\subsubsection{Preek as lewe in bewoënheid}

Handelinge 20:19:

Ek het die Here in alle nederigheid gedien, te midde van droefheid.

Paulus se lewe as slaaf van die Here was nie net 'n lewe in nederigheid nie, maar ook 'n lewe (letterlik) van trane. Dit is opvallend 
dat nederigheid en droefheid hier in een sin bymekaar gevoeg word. Dié uitdrukking hou nie in dat Paulus die hele tyd in trane was nie. Dit hou wel in dat hy, terwyl hy sy werk in diens van die Here gedoen het, dikwels rede tot trane gehad het (Newman \& Nida 1972: 389). In Paulus se trane sit egter nog meer. Daarin bewys hy ook sy opregte omgee en sorg as herder vir die gemeente in Efese (Kistemaker 1995:734). Paulus se hele bediening in die gemeente was nie 'n hartelose, koue bediening van die waarheid nie. Sy prediking vloei deur 'n teer en warm hart na die gemeente (Alexander 1991:253; vgl. Keddie 1993:261). Vir die prediker om as preek op te tree, is

... not a position or power, it is a matter of deep-felt compassion, care and concern, coupled with spirituality of life and a thorough knowledge of the Word of God (Phillips 1991:407).

'n Prediker is 'n preek as hy dien in bewoënheid vir die gemeente van die Kurios, Oorwinnaar.

\subsubsection{Preek (lewe) as opoffering en lyde vir die evangelie}

In Handelinge 14:19-22 is die volgende van belang:

... hulle (die Jode) het Paulus met klippe gegooi en hom uit die stad gesleep, onder die indruk dat hy dood is.

In vers 22 staan dat Paulus en Barnabas die gelowiges geestelik versterk het en hulle aangespoor het in die geloof. "Ons sal eers deur baie verdrukking moet gaan voordat ons in die koninkryk van God kom", het hulle gesê.

Die evangelie is verniet, maar die evangelie is nie goedkoop nie. Presies dit is wat Paulus hier ervaar as hy uit die stad gesleep en gestenig word en vir dood agtergelaat word. Die diepste kern vir die antagonisme teen Paulus is dat hy verkondig het dat Jesus van Nasaret die beloofde Messias was. En tog staan Paulus op uit die steniging en besoek opnuut die gemeentes wat pas gestig is en keer daarna terug na Sirië en Antiogië — juis om die gemeentes te versterk en te bemoedig. Hierdie twee uitdrukkings het byna tegniese terme geword vir Paulus se werk met nuwe gelowiges (vgl. Stott 1991:234).

Die punt van belang hier is die feit dat Christus gely het en dat sy volgelinge ook daarom sal ly en moet opoffer. Verdrukking is on- 
miskenbaar deel van die lewe van 'n prediker. Die uitdrukking wat hier vir "verdrukking" gebruik word, word in die Nuwe Testament meermale in verband gebring met die gelowiges se lyding in die eindtyd. Verdrukking ly is nie 'n opsie vir 'n prediker nie, dit is 'n goddelike moet. Verdrukking vanuit die goddelike kan daartoe dien om die prediker (verder) tot preek te omvorm.

\subsubsection{Preek (lewe) as gehoorsaamheid}

Handelinge 13:4:

So is Barnabas en Paulus deur die Heilige Gees uitgestuur. Hulle het na Seleukië toe gegaan...

Verse 2-4 van Handelinge 13 is vol van die aksie van die Heilige Gees. Dit is die Heilige Gees wat sê: "Sonder Barnabas en Paulus vir My af" (vers 2a) "om die werk te doen waarvoor Ek (die Heilige Gees) hulle geroep het" (vers $2 \mathrm{~b}$ ). En in vers 4 staan: "So is Paulus en Barnabas deur die Heilige Gees uitgestuur". Dan volg: "Hulle het gegaan" (vers 4).

Op die stuur van die Heilige Gees volg (in gehoorsaamheid) die gaan van Paulus en Barnabas. Die Heilige Gees is spesifiek in wie Hy roep, maar is hier nie spesifiek oor die bestemming waarheen Hy hulle roep nie. Dit skyn asof die keuse van die bestemming aan Paulus en Barnabas oorgelaat word " ... because these were men of the Holy Spirit, sensitive to His leading” (Kim 1999:112). Johnson (1997:225) wys daarop dat hierdie absolute gehoorsaamheid ook sterk na vore kom in Paulus se vaste voorneme om na Jerusalem te gaan. Ook in daardie voorneme staan die werk van die Heilige Gees sentraal: "En nou gaan ek Jerusalem toe, daartoe gedwing (letterlik gebind) deur die Heilige Gees" - en dit terwyl die Heilige Gees self vir Paulus gewaarsku het dat lyding in Jerusalem op hom wag (vgl. Johnson 1997:225).

Absolute gehoorsaamheid aan God en sy roeping en opdrag maak van 'n prediker 'n preek. 
2.2.8 Preek (lewe) as heilige verontwaardiging Handelinge 17:16-17:

Terwyl Paulus in Athene vir Silas en Timoteus wag, het by baie verontwaardig geword toe by sien hoe vol afgodsbeelde die stad is. Hy het in die sinagoge met die Jode en die godvresendes geredeneer...

Die drakrag van die uitdrukking dat Paulus "baie verontwaardig" geword het, moet nie misgelees word nie. Die verontwaardiging het nie voorgekom uit 'n slegte humeur nie, of uit jammerte vir die Ateners se onkunde nie. Die verontwaardiging vloei voort uit: “... a heart of rigtheous and holy anger" (Calvyn 1966:104), 'n hart

which aroused within him deep stirrings of jealousy for the name of God as he saw human beings so depraved as to be giving to idols the honour and glory which were due to the One, living and true God alone (Stott 1991:279).

Phillips (1991:346) wys daarop dat die uitdrukking "verontwaardig geword" in die Septuagint feitlik deurgaans gebruik word in verband met die toorn van God, veral in sy reaksie teen afgodery, soos toe sy volk Israel die goue kalf gemaak het en later ook Baäls aanbid het. Dit kan dus gesê word dat Paulus se verontwaardiging nie gerig was teen die Ateners nie, maar teen Satan wat die Atheners verslaaf het aan afgodsbeelde. En wat tog opvallend is, is dat dit die heilige verontwaardiging is wat sy mond open en hom laat optree as prediker (Stott 1991:280). Heilige verontwaardiging waar dit gaan om God se eer en die handhawing van God se eer, bevestig die eenheid van die prediker en preek.

\subsubsection{Preek (lewe) as integriteit}

Handelinge 20:33:

Ek het niemand se geld of klere begeer nie.

Elke prediker het reg op geldelike onderhoud deur die gemeente waarin hy dien. Maar as die prediker as preek (dus deur sy lewe) uitstraal dat hy baie geld begeer, is dit 'n gebrek aan integriteit teenoor God en teenoor sy roeping.

Paulus behandel hier die prediker se gesindheid en gedrag in geldsake of in besittings. Hy sê dat hy dit nie "begeer" nie. Hierdie begrip 
... may be rendered in some languages as "wanting to take away someone's possession, or wanting for myself what belongs to someone else" (Newman \& Nida 1975:397).

Die vereiste dat 'n prediker nie 'n geldgierige moet wees nie, beskerm hom teen twee wesenlike gevare. Die eerste is om die prediking te besoedel deur God se Woord te gebruik om homself te verryk. Die tweede is om die prediking te verwaarloos om ryk te word deur projekte buite die bediening (MacArthur 1992:97).

'n Prediker kan nie slaag in sy prediking nie, maar druip in sy preke (lewe) as begeertes om ryk te word sy gedagtes en dade oorheers.

\section{KONGRUENSIE TUSSEN PREDIKER EN PREEK - HOE?}

\subsection{Gebed}

In literatuur word bepaalde geloofsaksies uitgesonder waar gehandel word oor kongruensie tussen prediker en preek. Hierdie aksies is gebed, omgang met God deur sy Woord en bepeinsing van die Woord.

Oor die noodsaaklikheid van gebed in 'n lewe van 'n prediker, is reeds wyd geskryf. Roloff (1988:131) behandel veral die gesindheid in die gebed, naamlik om gewillig en begerig te wees om jou voor God te stel. Lea en Griffin (1992:84) wys op die noodsaak van gereelde en herhaalde gebed en Capill (2003:189) beklemtoon absolute nederigheid voor God in die prediker se gebedslewe. Dit is opvallend dat outeurs telkens en veral gebedsgesindheid beklemtoon.

Die vraag hier is of in Paulus se preke in Handelinge sprake is van gebed en in besonder van die vereiste gesindheid, om prediker en preek in kongruensie te hou. In Handelinge 20:36 word gestel:

Nadat Paulus dit gesê het, het hy saam met hulle almal gekniel en gebid.

Aan die einde van sy preek kniel Paulus en bid saam met die ouderlinge. Die werkwoord "kniel" het besondere betekenis ten opsigte van die gesindheid waarin gebid word. Die gebruiklike gebedshouding was om te staan. By uitsonderlike geleenthede is gekniel (Marshall 1991:337). Die knielende gebedshouding het 'n diep gevoel van smart, 
hulpeloosheid en skuldgevoel in die hart van die bidder uitgedruk (Kim 1991:123).

Calvyn (1966:190) sien drieërlei betekenis in 'n knielende gebedshouding: dat al die bidder se ledemate gebruik word om God te eer, dat die bidder deur te kniel as't ware uitgeruk word uit 'n houding van gebedsluiheid (kniel verg inspanning) en, laastens, "in this way the sons of God profess their piety, and they inflame each other with reverence of God" (Calvyn 1966:190). Williams en Larkin (1995:300) sien die knielende gebedshouding as die betuiging van totale afhanklikheid van God.

Nie net vir en saam met die ouderlinge van Efese bid Paulus knielend nie. As hy vir die gemeente van die Efesiërs bid, kniel hy ook: "Daarom kniel ek in gebed voor die Vader..." (Efesiërs 3:14). In Handelinge 20:36 lê die klem op die gebedshouding, in Efesiërs 3:14 word die inhoud van dit waarvoor Paulus knielend bid uiteengesit as die rykdom van die Gees (vers 16), dat Christus deur die geloof in die gemeente se harte sal woon (vers 17) en dat die gemeente in staat sal wees om die volle omvang van die liefde van God te begryp (verse 18-19).

Die gesindheid in die gebed moet dus dié wees van nederigheid, oorgawe, afhanklikheid en van 'n lewe in godsvrug. Die inhoud van so 'n gebed behoort die volgende aspekte in te sluit:

- die belydenis van eie skuld waar prediker en preek (lewe) nie saamval nie;

- die gebed om berou,

- die gebed om die rykdom van die Gees,

- om die inwoning van Christus,

- asook om te kan lewe uit die omvangryke liefde van God (vgl. Capill 2003:189).

\subsection{Omgang met die Woord van God}

Handelinge 17:11 word nader ondersoek, veral met die oog op die gesindheid waarin met die Woord van God omgegaan behoort te word.

Die mense daar (in Berea) was ontvankliker as dié in Tessalonika. Hulle het met groot belangstelling na die woord geluister en elke dag die Skrif ondersoek om te sien of dit is soos Paulus sê. 
Die uitdrukking dat die mense in Berea "ontvankliker" was vir die woord as die in Tessalonika, hou letterlik in dat die mense in Berea edelgeborenes was, van koninklike afkoms — en dus ook koninklike kwaliteit openbaar het in hulle omgang met die woord (Kim 1999:121). Hulle het die woord bestudeer met 'n ontvanklike hart en 'n oop gemoed, "... the qualities that go with good breeding" (Polhill 1992:363).

Nie net was die mense van Berea ontvanklik vir die woord van Paulus nie, hulle het ook met groot belangstelling daarna geluister. Hulle het die woord as't ware begeer, daarna verlang,

their heart - response to Scripture was one of accepting and believing it. They were prepared to be led where ever the Word of God led them (Keddie 1993:205).

Hierdie nadere of noukeurige ondersoek van die woord was 'n daaglikse roetine. Hulle het dit wat Paulus verkondig het, in die Ou Testament daagliks nader bestudeer. Daaglikse ondersoek van die woord hou ook in 'n patroon van gereelde herhaling

after having read a sentence, [they] returned to treat the lines again, in orde that the track of the sense might be more deeply graven on the minds (Kim 1999:121).

Hierdie ondersoek het nie vanuit 'n gesindheid van ongeloof en twyfel plaasgevind nie, maar vanuit 'n gretigheid om die boodskap van God se openbaring hulle eie te maak en toe te pas.

Prediker as preek kan net slaag as die prediker met toewyding, met oopstelling van sy eie gemoed en deur gereelde, gesonde gewoonte die Woord van God bestudeer en sy eie maak deur die Woord in te neem om daardeur gevoed te word.

\section{SAMEVATTENDE STELLINGS}

4.1 Navorsing oor ' $n$ onderwerp soos die prediker as preek behoort sy vertrekpunt in die Pneumatologie te neem, want dit is die Gees wat aanstel, roep, vervul en dwing — ook tot kongruensie tussen prediker en preek.

4.2 Inhoudelik kan die volgende aspekte onderskei word in die preek (=lewe) van die prediker 
- Passie om selfs ten koste van die eie lewe, die bediening deur God opgedra, te voltooi.

- Innerlike getrouheid en integriteit om die volle heilsplan van God te verkondig en ook in die eie lewe toe te pas.

- Kongruensie tussen prediker en preek word bevorder deur te werk en te lewe in nederigheid, dit wil sê in die erkenning van eie swakheid en in verwondering oor wie die Kurios is en wat Hy doen.

- Om in bewoënheid te dien en te leef, is om dit te doen in die krag van die Kurios.

- Die evangelie is verniet, maar nie goedkoop nie. Die verdra en verwerking van eie lyding en opoffering kan daartoe meewerk om prediker en preek verder in kongruensie te bring.

- Absolute gehoorsaamheid aan God, sy roeping en opdrag maak van 'n prediker ook 'n preek.

- Heilige verontwaardiging vir God se eer en die handhawing daarvan, bevestig die eenheid tussen prediker en preek.

- 'n Gebedsgesindheid van nederigheid, oorgawe en afhanklikheid is noodsaak vir die eenheid tussen prediker en preek.

- 'n Prediker kan net as preek slaag as hy met toewyding, oopstelling van sy eie gemoed en deur gereelde, gesonde gewoonte die Woord van God bestudeer, sy eie maak en toepas. 


\section{BIBLIOGRAFIE}

Alexander J A

1991. A commentary on the Acts of the apostles (II). Edinburgh: Banner of Truth.

\section{BUTTRICK D}

1994. A captive voice. The liberation of preaching. Westminster: John Knox.

\section{CALVIN J}

1966. The Acts of the Apostles (14-28). Grand Rapids: Eerdmans.

\section{CAPILl M A}

2003. Preaching with spiritual vigour: including lessons from the life and practice of Richard Baxter. Ross-Shire: Christian Focus.

\section{CRADDOCK F B}

1985. Preaching. Nashville: Abingdon.

\section{DingEMANS G D J}

1991. Als hoorder onder de hoorders. Een hermeneutiese hermeneutiek. Kampen: Kok.

\section{GREEN G}

1996. The crisis of mainline Christianity and the liberal failure of imagination. Review In Religion and Theology 9(18):9-21.

\section{HENDRIKS H J} 1995. South African denominational growth and decline 1911-1991. Journal of Theology for Southern Africa 91:35-58.

\section{JOHNSON D E}

1997. The message of Acts in the history of redemption. Phillipsburg: $\mathrm{P} \& \mathrm{R}$.

\section{KedDie G J}

1993. You are my witnesses: the message of the Acts of the Apostles. Darlington: Evangelical.

\section{KELLER D}

2002. If the medium is the message, how is the preacher the sermon? Chicago: Evangelical Homiletical Society.

\section{KIM H K}

1999. Preacher and spirituality. A homiletical study in the light of Paul's sermons in Acts 13, 14, 17 and 20. Potchefstroom: PU vir CHO. Th. D.-proefskrif.

\section{KIM N J}

1993. Renewal of the church and recovery of preaching. Seoul: Soloman.

\section{KisTEMAKER S J}

1995. Acts. Grand Rapids: Baker.

\section{LEA T D \& GRIFFIN H P (jr.)}

1992. 2 Timothy, Titus. Nashville: Broadman. 
LUTZER E

1998. Pastor to pastor. Tackling the problems of ministry. Grand Rapids: Kregel.

MACARTHUR J (jr.)

1992. The man of God and expository preaching. In: J. MacArthur (jr.) (ed)., Rediscovering expository preaching (Dallas: Word), pp. 85-101.

\section{Marshall I H}

1991. The Acts of the Apostles. Leicster: Inter-Varsity.

\section{MAWHINNEY B}

1997. Preaching with freshness. Grand Rapids: Kregel.

\section{MitChell M}

1993. The hearers' experience of the Word. In: O'Day \& T. Long (eds.), Listening to the Word (Nashville: Abingdon), pp. 223-242).

\section{Mulder J M}

1991. The re-forming of American protestantism. Reformed Review 44(3):203211.

\section{NeL M}

2001. Ek is die verskil. Die invloed van persoonlikheid in die prediking. Bloemfontein: CFR.

Newman B M \& Nida E A

1972. A translator's handbook on the Acts of the Apostles. New York: United Bible Society.

\section{OGILVIE L J}

1984. Acts. Waco: Word.

\section{PHILLIPS J}

1991. Exploring Acts. Neptune: Loizeaux Brothers.

\section{Pieterse H J C}

2001. Prediking in 'n konteks van armoede. Pretoria: Unisa.

PolHILl J B

1992. Acts. Nashville: Broadman.

\section{RIENECKER R}

1976. A linguistic key to the Greek New Testament 1. Grand Rapids: Zondervan.

1980. A linguistic key to the Greek New Testament 2. Grand Rapids: Zondervan.

\section{ROBINSON H W}

1999. Expository preaching: principles and practice. Leicester: IVP.

\section{RolofF J}

1988. Der erste Brief an Timotheus. Zurich: Beuziger. 
RUNIA K

1983. The sermon under attack. Exeter: Paternoster.

Sтотт J

1991. The message of Acts. Leicester: Inter-Varsity.

VORSTER J M

1996. Is die kerk funksioneel? Gedagtes oor Gereformeerde kerkvernuwing in 'n postmodernisme konteks. Potchefstroom: Potchefstroomse Teologiese Publikasies.

WILLIAM J \& LARKIN J

1995. Acts. Downers Grove: Inter-Varsity.

Trefwoorde

Prediker

Gesindheid

Kongruensie

Lewenswandel
Keywords

Sermon

Attitude

Congruence

Way of conduct 